\title{
Why Attacks on Civic Space Matter in Strasbourg: The European Convention on Human Rights, Civil Society and Civic Space*
}

\author{
Por qué los ataques al espacio cívico \\ son importantes en Estrasburgo: \\ el Convenio Europeo de Derechos Humanos, \\ la sociedad civil y el espacio cívico
}

Antoine Buyse

Utrecht University

a.c.buyse@uu.nl

Summary: 1. Introduction. 2. Civil society and civic space and the link to democracy and human rights. 3. Civil society and the European Court of Human Rights: the procedural options. 4. Civic space issues at the European Court: substantive protection. Conclusion. References.

\begin{abstract}
This article explores the role of the European Convention on Human Rights in addressing the issue of attacks on civic space, but also the potential effects of shrinking civic space on Strasbourg's work. First, an overview of the notions of civil society and civic space is given, linking these concepts to democracy and human rights. Subsequently, the formal and informal roles for civil society in the judicial decision-making are discussed. Finally, the substantive protection offered to civil society and civic space under the ECHR and the case-law of the European Court of Human Rights is analysed. This article argues that the differentiations in theory on the varying contributions of civil society to democracy and human rights are to a large extent reflected in Strasbourg jurisprudence. Even more importantly, the ECHR system and civil society benefit from each other. This is why the current attacks on civic space are not just a problem for civil society itself, but also for the

* Citation: Buyse, Antoine. 2019. "Why Attacks on Civic Space Matter in Strasbourg: The European Convention on Human Rights, Civil Society and Civic Space". Deusto Journal of Human Rights, no 4: 13-37. http://dx.doi.org/18543/djhr-42019pp13-37
\end{abstract}


work of the European Court: it is submitted that a shrinking of civic space can also negatively affect the Strasbourg system, as the two are intertwined to a considerable extent.

Keywords: civic space, civil society, European Convention on Human Rights, ECHR, freedom of association, freedom of assembly, freedom of expression.

Resumen: Este artículo analiza el papel del Convenio Europeo de Derechos Humanos a la hora de abordar el tema de los ataques al espacio cívico, pero también los posibles efectos de la reducción del espacio cívico en el trabajo del Tribunal de Estrasburgo. Primero, se ofrece una visión general de las nociones de sociedad civil y espacio cívico, vinculándolas con la democracia y los derechos humanos. Posteriormente, se discuten los roles formales e informales de la sociedad civil en la toma de decisiones judiciales. Por último, se analiza la protección sustantiva ofrecida por el CEDH y la jurisprudencia del Tribunal Europeo de Derechos Humanos a la sociedad civil y al espacio cívico. Este artículo defiende que las diferencias teóricas sobre las diversas contribuciones de la sociedad civil a la democracia y los derechos humanos se reflejan en gran medida en la jurisprudencia de Estrasburgo. Más aún, el sistema del CEDH y la sociedad civil se refuerzan mutuamente. Esta es la razón por la que los ataques actuales al espacio cívico no son solo un problema para la sociedad civil, sino también para el trabajo del Tribunal Europeo: se considera por ello que una reducción del espacio cívico también puede afectar negativamente al sistema judicial de Estrasburgo, ya que ambos están estrechamente relacionados.

Palabras clave: espacio cívico, sociedad civil, Convención Europea de Derechos Humanos, CEDH, libertad de asociación, libertad de reunión, libertad de expresión. 


\section{Introduction}

"I'm officially telling human rights defenders (...) Chechnya will be a forbidden territory for them, like for terrorists". This remarkable statement was made in the Summer of 2018 by Chechnyan leader Ramzan Kadyrov when commenting on a trial against a human rights defender (Human Rights Watch, 2018). Almost a year later, in March 2019, a local Chechnyan court sentenced that defender, Oyub Titiev, to four years in a penal colony. The formal charge was possession of marihuana, but fellow human rights activists thought the drugs were planted in his car on purpose and alleged that the probable real trigger for his conviction were his revelations about torture and abductions by security services in the region (The Guardian 2019). They were not the only ones. A month before his conviction, the European Parliament had called for Titiev's immediate release. Tellingly, it saw his detention as part of a wider problem by expressing "its deep concerns over the worrying trend of arrests, attacks and intimidation of independent journalists, human rights defenders and their supporters, and ordinary citizens alike, which appear to be part of coordinated campaigns" 1 .

Indeed, the arrest and trial do not seem coincidental. Tityev headed the Chechen branch of Russian human rights group Memorial, a civil society organisation (CSO) focused on memorialising past human rights violations and addressing current ones. In 2016, the group was declared a "foreign agent" under the Russian Federation's law that obliges organisations receiving foreign funding and undertaking "political activities" to declare themselves foreign agents. Not without a certain twist of irony, Memorial was labelled as such for criticising that very law, because that type of criticism was considered a political activity (The Moscow Times, 2016). The night before the law came into force, its Moscow headquarters building had been sprayed with graffiti carrying the text "foreign agent".

These very diverging actions - criminal prosecution, administrative law measures, and vigilante action in the form of graffiti- reflect the different faces of adversity faced by human rights work in present-day Russia. They do not stand on their own, however. Geared as they are against critical voices speaking out, such actions are part of a much wider global trend often summarised under the label of attacks on civic space, which could be defined as the practical room for (collective)

1 European Parliament, Resolution on the situation in Chechnya and the case of Oyub Titiev, 14 February 2019 (2019/2562(RSP)). 
action for citizens and CSOs. ${ }^{2}$ Indeed, the last fifteen years show a trend in which the freedoms of speech, association and assembly have come under increasing pressure, both from states and from non-state groups. As the civil society 'umbrella' organisation CIVICUS noted in its annual report over 2018, peaceful activism by people faced structural attacks in 111 out of 196 countries monitored. Europe was no exception to this trend (CIVICUS 2018). Such attacks may vary from verbal and physical attacks on journalists, to disruption of protests, prosecution of those taking part in them, and severe restrictions on the activities of civil society organisations. Those active in the field of human rights seem to be particular targets.

Civil society has responded in different ways to these attacks. One tactic has been to bring cases to the European Court of Human Rights. This is what Memorial did in 2013. And it was not the only organisation availing itself of this legal procedure. In 2013 and the following years 49 civil society organisations active in Russia did the same. $^{3}$ This begs the question to what extent Europe's most important legal system of protection of fundamental rights, that of the European Convention of Human Rights (ECHR), is dealing with challenges to civic space. In order to answer this question, this article will first delve into the notions of civil society and civic space and their links to democracy and human rights. Subsequently, some key procedural aspects of civil society litigation in the ECHR system will be described. In addition, a number of core elements of the Court's case-law on civil society and the protection it should receive under the ECHR will be analysed. Finally, it will be argued in conclusion that the mutually beneficial potential of domestic civil society and the European human rights protection system also works the other way around: a weakening of the former through the phenomenon of attacks on civil space may also negatively affect the latter. Thus, the shrinking of civic space is an urgent issue that should also matter in Strasbourg.

\section{Civil society and civic space and the link to democracy and human rights}

Civil society is one of those the most elusive and contested concepts in social sciences and many attempts have been made to

2 See the definition in section 2 of Buyse (2018).

3 European Court of Human Rights (ECtHR), ECODEFENCE and others v. Russia and 48 other applications, Appl.no. 9988/13 a.o., communicated case. 
define it. ${ }^{4}$ A very traditional way to define it was to delineate what it is not: it is not the family, the state or the market. A rich literature on civil society and its virtues and problematic aspects has emerged in the past two centuries: from Alexis de Tocqueville's enthusiastic liberal description of the forming of voluntary associations in the $19^{\text {th }}$-century United States, to neo-Marxist Antonio Gramsci who conceptualised civil society as an arena of contestation, which could both strengthen or resist the hegemony of the (bourgeois) powers that be, all the way through to Jürgen Habermas who saw an ideal, healthy civil society as a public sphere in which its members construct shared meanings through democratic deliberation (Edwards 2014, 18-19).

More practically, for current purposes, is to specify that civil society is the totality of groups and people who associate voluntarily around common goals or interests (see e.g. Anheier 2004, 20). This can range from very organised and formally established civil society organisations to informal social movements or advocacy groups and even to ad hoc gatherings or demonstrations. The classic notion of separateness from state and market has been nuanced in recent years by pointing to a blurring of boundaries between the three (Centre for Civil Society 2006). Indeed, many hybrids have emerged. One may think of social enterprises or organisations providing public-type services such as healthcare (World Economic Forum 2013).

The variety of forms does matter. It should be noted that the more established formal organisations have often served as supporters or facilitators of broader, more loosely grouped social movements (World Economic Forum 2013, 6). However, their modes of operation may be so divergent that cooperation can at times be difficult, uneasy or even impossible, even in the field of human rights. Tactics aimed at disruption by street protesters represent a very different mode of action than, for example, litigation in courts by established human rights organisations (Lettinga and Kaulingfreks 2015). Both aim to contest the status quo, but to different extents and in very different ways. Yet, the very variety of and the interactions between different parts of civil society in a given country reflect its strength. An "associational ecosystem", as civil society theorist Michael Edwards has called it, that becomes too homogeneous can erode or even collapse (Edwards 2011, 8).

Whereas from a sociological perspective, any voluntary association of people may qualify as civil society, for both political scientists and legal scholars the types of activities undertaken and the roles of

${ }^{4}$ For a good and wide-raging overview, see: R. Cooper (2018). 
different types of associations are relevant. In a broad sense, both armed groups committing genocide and gatherings peacefully calling for a less corrupt government could theoretically be seen as civil society. But if one takes a more content-laden position and puts an emphasis on the notion of "civil" in civil society, then the differences do matter. Civility has not just been linked to polite manners, but also to non-violence and even tolerance and the consideration of other people as equals. To avoid getting stuck in unending moral debates, it has been suggested that the difference between adherence to or violation of human rights may serve as a yardstick to assess civil society (Glasius 2016). However, the very fact that such "bad civil society" may be opposed to liberal democracy, also weakens the clout of human rights-based approaches and procedures, as they may fall in the category of "too little and too late" once bad civil society gains influence (Chambers and Kopstein 2001, 859-860). Timeliness in dealing with such groups is thus essential. On the other hand, the labelling of civil society groups as dangerous or extremist in order to silence them has been a much-used tactic by governments in recent years (Human Rights Watch 2016). Drawing lines between legitimate and illegitimate civil society groups should thus be approached with great caution and is far from self-evident, as such distinctions all rest on assumptions about the purpose of civil society.

Such typologies do matter in the context of attacks on civic space. Not just because of labelling, but also because restrictive state measures are often justified by references to the need to combat undesirable activities, movements or organisations. By contrast, international organizations such as the Council of Europe, in whose context the ECHR system functions, have taken an approach that emphasizes the value of civil society rather than its dangers: its important or even essential contribution to democracy and human rights. ${ }^{5}$

So how does civil society relate to democracy and human rights then? If one sees democracy as more than mere elections, civil society greatly matters. It is through the pooling of common opinions or interests in associations or other more informal groups that people can exchange views, organise pressure or scrutiny, and mobilise. Organisations can function as watchdogs, as conveyors of those

5 Committee of Ministers of the Council of Europe, Recommendation CM/ $\operatorname{Rec}(2007) 14$, on the Legal Status of Non-Governmental Organisations in Europe, adopted 10 October 2007 and Recommendation CM/Rec(2018)11, on the need to strengthen the protection and promotion of civil society space in Europe, adopted on 28 November 2018. www.coe.int 
who are otherwise voiceless, and as promoters of accountable and transparent government (or more broadly anyone who wields power in a given society, even from the private sector). Civil society groups can also, if participatory channels function well, bring in expertise into state institutions not otherwise available. For these reasons they have been called the "social basis for democracy" (WEF 2013, 11). And one could also argue the other way around. The demise of a well-functioning civil society or even its deliberate destruction fatally weakens democracy. Both the modern market-economy, certain forms of new public management as well as authoritarian leaders can cause "two opposite but eerily similar pathologies facing democratic orders". These are an atomistic type of individualism, which weakens people's roles and skills as citizens (by approaching them mostly as consumers or users of services), and an isolating type of totalitarianism, which makes people retreat from the public sphere for fear of repercussions (Chambers and Kopstein 2001, 838).

To fulfil any role at all, civil society needs specific human rights, such us the freedom of assembly, association and expression and more broadly the right to participate. All of these are necessary to foster deeper forms of democracy than the mere holding of elections and thus extend far beyond a mere right to vote or to stand for elections. Human rights can also serve as protective umbrellas for unpopular, critical or minority views. Thus human rights are instrumental to civil society. But greater human rights protection or the furtherance of specific human rights can also be a goal of civil society. A social movement may advocate for better implementation of the right to housing or education, for example. As will be shown below, human right institutions such as the European Court of Human Rights, closely connect human rights and democracy in caselaw. It is thus crucial to be able to evaluate the role of civil society in democracy.

It is clear from the above that certainly not all actors within civil society will contribute. Some movements may even seek to destroy democracy. Or they may simply serve to support existing state and power structures (Wischermann et al. 2018). Political scientist Mark Warren has theorised about the potential contributions of civil society to democracy. He defines democracy in a broad sense in that it requires that "all those potentially affected by collective decisions have opportunities to affect those decisions in ways proportional to the potential effects" (Warren 2011, 378). This definition again shows the importance of the human rights identified above, as one needs to be able to voice opinions, organise and participate in order to reach this 
ideal. Warren identifies three perspectives or dimensions to assess the contributions of a specific group in civil society to democracy.

The first dimension is the degree of voluntariness: states in which many associations with involuntary elements exist, ranging from criminal or clientelist groups and, to different degrees, ethnic or religious groups, may reproduce existing power inequalities within those groups and beyond them rather than support the democratic effects of elections. Groups based on a large degree of voluntary joining may be more beneficial. This reflects the notion of civil society as professed by, for example, the European Parliament as the sphere of non-coercive [my emphasis] association (Youngs and Echagüe 2017). ${ }^{6}$ The degree of internal democracy also matters here: if associations are organised in top-down authoritarian ways with little space for free deliberation, then the assumption that civil society is beneficial for democracy in a broader sense does not fly (Wischermann et al. 2018, 111). In such cases they do not function as small-scale laboratories for people to gain experience in democratic attitudes and decision-making. So-called GONGOs (Government-Organised NGOs) may be a point in case.

The second dimension are the constitutive media towards which a civil society group is oriented: social norms, the power of the state, or the market. A group committed primarily to accountability of policymakers may have a very different degree of contribution to democracy than a consumer organisation striving to push toy producers to make those more affordable. Here, the linkage with the first dimension matters, as a consumer organisation that is highly democratically organised may be beneficial to fostering democratic attitudes of its members.

The third relevant dimension is that of the group's purposes: it matters greatly whether it pursues aims that are primarily public, identity-based or status-based. According to Warren, striving to promote public goods, such as clean air or security, can only be done through collective action. The deliberation, convincing and mobilising which this entails most tends to increase civic virtues and capacities and thus has the greatest prospect of contributing to democracy. For a well-functioning "democratic associational ecology", a balance is required between different types of organisations. Societies may be highly organised around ethnic or religious groups but that does not

6 Others also espouse this characteristic of voluntariness as part and parcel of a definition of civil society (e.g. Anheier 2004: 20). 
equal automatically a greater chance of yielding democratic citizens (Warren 2011, 383-387).

Having delved into the conceptions of civil society and their linkages to human rights and democracy, we will now turn to civic space. As stated above, this space represents the practical room for civil society to function. This can be in the form of physical space, for example the ability and security to organise a demonstration in a public square or to have safe office space that will not be attacked. But it is also space in a more metaphorical, Habermasian sense, such as the possibility to freely express oneself online or to function as an organisation. The degree to which specifically the right to assembly, association and expression are respected and secured, both by states and non-state actors reflects a human rights approach to assessing the extent of civic space in a country.

A useful way to analyse the attacks on civic space is to identify the three different levels in which these attacks play out: institutionally, in discourse, and in practice (Van der Borgh and Terwindt 2014, 38). At the level of formal institutions and norms, many laws and policies have been introduced which make the registration and functioning of civil society organisations more difficult. Certain types of activities have been prohibited and access to funding, especially across borders, has been made more difficult. In spite of the ratification of human rights treaties protecting the above-mentioned rights and in spite of formal calls on states by for example the United Nations Human Rights Council in many subsequent resolutions of the past years to "create and maintain, in law and in practice, a safe and enabling environment in which civil society can operate free from hindrance and insecurity"7, the global trend seems to go in the opposite direction. Between 2012 and 2017, there were twice as many proposed and enacted restrictive national laws and policies than enabling ones (Coelho 2017). At the level of discourse, civil society activists and organisations have been vilified by both governments and online trolls as traitors, extremists or worse. This can have an intimidating effect on the work of civil society groups and delegitimise them (Carothers and Brechenmacher 2014, 11). Finally, at the level of practical room for manoeuver for civil society, human rights activists have faced a range of difficulties, ranging from co-optation by the state to weaken them, to the closure of websites or even the use of violence against them. ${ }^{8}$ Very often there

7 E.g. United Nations Human Rights Council, Resolution 32/31, Civil society space, 1 July 2016, UN Doc A/HRC/RES/32/31, para. 4.

8 For examples, see Buyse (2018). 
is an interaction between threats to individuals and difficulties for the organisation to which they are connected. The parallel difficulties for both Oyub Tityev as a person and for Memorial as an organisation illustrate this negative and often deliberate spill-over between the individual and the organisational levels in terms of space to act. At worst, this has even wider ripple effects, chilling the activities of civil society in a broader sense, especially those parts that are deemed a nuisance to the powers that be. Thus, there are strong indications that civic space is under attack in many places.

\section{Civil society and the European Court of Human Rights: the procedural options}

The relationship between civil society and the system of supervision established under the European Convention on Human Rights is closely knit. On the one hand, civil society in Europe has greatly contributed to the development and strengthening of the system -and this is why attacks on civic space can also negatively affect the well-functioning of this European system. The positive contribution has happened both in terms of access, practically and procedurally, but also in terms of development of the Court's jurisprudence. The substantive protection of the Court's case-law is the subject of the next section, but it is important to note already here that the protection offered by that substantive elaboration and clarification of Convention rights helps to protect civil society within states. In this section, however, the focus will be on access and procedure. Civil society can play a role in three stages: before, during and after proceedings.

The first stage relates to the bringing of a case. As Article 34 of the Convention states "any person, nongovernmental organisation or group of individuals claiming to be the victim" of a violation of ECHR rights can bring a complaint to the European Court. It is thus not limited to natural persons since legal persons, such as civil society organisations, can also complain. Relating to civic space issues this means that for example individuals or groups of protesters who have been arrested contrary to the right to liberty and organisations whose work has been interfered with or which have been dissolved can lodge complaints. Thus both the individual and the collective aspects of attacks on civic space can potentially be dealt with by the Court. One crucial limitation is that there is in principle no actio popularis. One cannot complain about human rights violations committed against others. In the example mentioned above, only those organisations hit 
in practical terms by executive action and/or domestic court decisions under the Russian Foreign Agents Act have been able to get their case taken into consideration by the European Court. Exceptions to this victim requirement are extremely rare. One was the Grand Chamber's judgment in Centre for Legal Resources On Behalf of Valentin Câmpeanu v. Romania. In that case, a civil society organisation was allowed to bring a complaint on behalf of a young man with a severe mental disability who had died in a psychiatric hospital. The Court considered that "in the exceptional circumstances of this case and bearing in mind the serious nature of the allegations" it could declare the case admissible. ${ }^{9}$ Of course, involvement in cases of others remains possible by acting as counsel for an alleged victim. And in more informal ways, civil society actors, ranging from human rights lawyers to organisations, have helped to increase awareness within states of the ECHR system as an avenue to claim rights. They have done so by providing information, trainings and courses, by giving advice to people considering to lodge a complaint and by collaborating across borders to pass on expertise (Cichowski 2010, 14).

Although in the very large majority of cases, the ideological, political or religious orientation of a civil society organisation is not relevant in the admissibility stage and the rights in the Convention in principle protect all types of civil society, there is an outer limit. The Court has applied Article $17 \mathrm{ECHR}^{10}$, the prohibition of the abuse of rights, to declare complaints inadmissible if the applicant individuals or organisations themselves espoused hatred, totalitarianism, or violence, antisemitism or islamophobia (Buyse 2014). Thus, for example, the Court declared a complaint of Hizb Ut-Tahrir, an association in Germany which had advocated the violent destruction of Israel and its inhabitants and had defended suicide attacks, inadmissible. ${ }^{11}$ Even if such cases are relatively rare, they do show that the Court has espoused a slightly value-laden conception of civil society. Applicants that go against the underlying values of the Convention, including

9 ECtHR, Centre for Legal Resources on Behalf of Valentin Câmpeanu v. Romania, 17 July 2014 (Appl.no. 47848/08) para. 112. One of the only other examples is: ECtHR, Association for the Defence of Human Rights in Romania - Helsinki Committee on behalf of lonel Garcea v. Romania, 24 march 2015 (Appl.no. 2959/11).

10 This provision reads: "Nothing in this Convention may be interpreted as implying for any State, group or person any right to engage in any activity or perform any act aimed at the destruction of any of the rights and freedoms set forth herein or at their limitation to a greater extent than is provided for in the Convention."

11 ECtHR, Hizb Ut-Tahrir and others v. Germany, 12 June 2012 (dec.) (Appl. no. 31098/08). 
democracy, cannot easily have their case heard. The acting upon uncivil values like violence or racist hatred is thus not condoned. Here, one can see that within the ECHR system a fully neutral sociological conception is not reflected. Rather, ideas about the civil and the uncivil, about good and bad civil society have found their way into the adjudication. This concerns a very small amount of cases or situations only, however. The case-law vehemently defends, as we shall see in the next section, a very wide array of views in civil society, including those that are unpopular with those in power.

In situations where civic space is under constant attack, either institutionally or by non-state actors, one could speak of structural violations of civil society rights. There are several procedural tools which the Court can apply in the pre-judgment stage - and thus before any substantive acknowledgement of the structural problem in the eventual judgment itself - if it assumes that a structural issue is at stake. Under its own Rules of Court ${ }^{12}$, it can decide to join and simultaneously examine two or more cases. It can do so either at its own motion or upon the request of one of the parties. This was done in several dozens of applications of civil society organisations complaining about the Russian Foreign Agents Law, for example. This joining makes most sense if the complaints relate to the same domestic law. If the structural issue is for example threats against or killing of civil society activists, then a joining seems much less probably, as the Court will prefer to assess each case's specificities and facts. The same will often, although not always, be the case for subsequent demonstrations which have been dispersed by state authorities. As a result, those type of attacks on civic space will be much more difficult to frame as a structural issue.

There is a final procedural tool in the pre-judgment phase at the disposal of the Court that can affect civic space cases: the priority policy. The very large volume of cases the Court has to adjudicate has caused long waiting times for applicants, often of many years before a judgment is issued. This is a general challenge in the Strasbourg system, but it also has consequences civic space issues. Especially if attacks on civic space are systemic or structural, this may affect not just civil society, but also weaken democracy, as argued in the previous section. Timing and speed are of the utmost importance in such instances, both when the state itself deliberately targets civil society, but also if non-state actors threaten civic space. A rights-based approach including long waiting times at the

12 Rule 42 of the Rules of Court: www.echr.coe.int/Documents/Rules_Court_ENG. 
European Court of Human Rights may in such cases risk to be too late to be effective. Since 2009, the Court has set up a priority policy enabling it to give precedence to more urgent cases. In its current configuration, first priority is given to risks to life and health of applicants and the right to liberty. This may be relevant when civil society activists are threatened or imprisoned. The second category includes situations which are "structural or endemic". ${ }^{13}$ There are thus a few possibilities here, which have not yet been used to full effect, as the fact that the first Foreign Agents law cases where lodged as far back as 2013 shows.

In the second stage, during proceedings, there is also an important entry point for civil society. Under Article $36 \mathrm{ECHR}$, the President of the Court can allow "any person concerned who is not the applicant to submit written comments or take part in hearings." This option of third-party interventions is further elaborated upon in Rule 44 of the Rules of Court. In practice, this possibility has not so often been used by individuals, but rather by civil society organisations, providing the Court with comparative legal research, insights from fields beyond law, and other expertise that may be of use and has often been of use in the Court's judicial reasoning (Bürli 2017). In the context of civic space issues, this option could be used to argue that a particular complaint is not a lone-standing human rights issue but part of more systemic problems for civil society. Apart from this formal way of intervening, there is another way in which the Court may avail itself of information gathered by civil society organisations: out of its own motion. It has done so mostly, but not exclusively, to assess country situations in cases concerning extradition or expulsion. ${ }^{14}$

Finally, in the third stage, once a judgment has been delivered, there is again an important possible role for civil society. On the one hand at the European level: the Committee of Ministers - the organ of the Council of Europe tasked under Article 46 ECHR with the supervision of the execution of the Court's judgments - can consider information brought to its attention by civil society organisations. ${ }^{15}$

13 European Court of Human Rights, Priority Policy, https://www.echr.coe.int/ Documents/Priority_policy_ENG.pdf

14 See e.g. ECtHR, Saadi v. Italy, 28 February 2008 (Appl.no. 37201/06), para. 131.

15 Rule 9 of the Rules of the Committee of Ministers for the supervision of the execution of judgments and of the terms of friendly settlements, CM/Del/ Dec(2006)964/4.4-app4consolidated. It can be noted that the Council of Ministers' Department for the Execution of Judgments actively welcomes such submissions from civil society to enhance its work, since it has created a specific website for organisations on how to submit: https://www.coe.int/en/web/execution/nhringo\#\%7B\%2244361690\%22:\%5B\%5D\%7D 
These organisations can, in doing so, pinpoint specific problems, including structural ones, in the implementation of judgments. In recent years, an umbrella network to help civil society to do this, the European Implementation Network (EIN) has been created. ${ }^{16}$ On the other hand, at the national level: depending on the legal system, judgments of the European Court can be used for strategic follow-up litigation, but also for advocacy, media campaigns and mobilization.

The above shows that civil society can greatly contribute and has greatly contributed to both the input to the ECHR system as well as to rooting it at the national level (Mclntosh Sundstrom 2014, 847). In this sense, the very existence of civic space within countries is important for the well-functioning of the European human rights protection system itself. If that space is under pressure, it may be difficult or even dangerous to become involved in Strasbourg cases and to advocate for the implementation of the Court's judgments at the domestic level. The Court has a real stake in civic space in that sense. Of course, it also works the other way around: for the problems civic space encounters, the substantive protection of specific rights protected under the European Convention, is also very important. It is to this issue that we will now turn.

\section{Civic space issues at the European Court: substantive protection}

The current case-law of the European Court of Human Rights does not include any explicit reference to "civic space" or "civil society space". ${ }^{17}$ However, space for civil society does feature in a myriad of ways in the jurisprudence. In this section, we will first look shortly at the notion of democracy in the case-law. Then, specific lines in the case-law relevant to civic space, developed foremost in cases concerning freedom of assembly, association and expression, will be addressed.

As was noted in section 2, civil society, depending on its ecology and the internal functioning of organisations and movements, may contribute to democracy. In the European Convention, the concept of democracy is deeply engrained. The Preamble already states that both democracy and human rights are the foundations of justice and peace.

16 See: www.einnetwork.org

17 As a search in the Court's search engine HUDOC, performed on 1 July 2019, revealed: https://hudoc.echr.coe.int/eng 
And a number of the rights protected in the ECHR can only be limited by states when "necessary in a democratic society". This includes the rights to freedom of expression, assembly and association (Articles 10 and 11 ECHR respectively). In the classic freedom of expression judgment of Handyside of 1976, the Court already connected notions of civility to democracy, holding that expressions that are shocking, offending or disturbing should in principle be protected because such "are the demands of that pluralism, tolerance and broadmindedness without which there is no democratic society." 18 A few years later, in the case of Young, James and Webster, the Court elaborated that democracy does not simply mean that what the majority decides should happen. Rather "a balance must be achieved which ensures the fair and proper treatment of minorities and avoids any abuse of a dominant position." 19 In 1998, it even held that democracy was the only political model compatible with the Convention. ${ }^{20}$ In later cases, for example relating to organisers of LGBT demonstrations in Russia, the Court specified that "it would be incompatible with the underlying values of the Convention if the exercise of Convention rights by a minority group were made conditional on its being accepted by the majority. Were this so, a minority group's rights to freedom of religion, expression and assembly would become merely theoretical rather than practical and effective as required by the Convention." 21 In that case, the use of public space by a minority de facto had to be protected against negative views of the majority of the population. Beyond freedom of expression and of assembly, the Court has also linked the freedom of association to a democratic society. It has held that the ways in which national laws and practical policies protect this freedom reflects the state of democracy in a country. Of course, associations should conform to domestic laws, but any restrictions put on free association should only be based on "convincing and compelling reasons" and will be rigorously supervised by the Court. ${ }^{22}$ In sum, the Court's case-law thus reveals a thick or deep conception of democracy,

18 ECtHR, Handyside v. the United Kingdom, 7 December 1976 (Appl. no. 5493/72), para. 49.

19 ECtHR, Young, James and Webster v. the United Kingdom, 13 august 1981 (Appl.nos. 7601/76 and 7806/77), para. 63.

20 ECtHR, United Communist Party of Turkey and others v. Turkey, 30 January 1999 (Appl.no. 19392/92), para. 45.

21 ECtHR, Alekseyev v. Russia, 21 October 2010 (Appl.nos. 4916/07, 25924/08 and 14599/09), para. 81.

22 ECtHR, Sidiropoulos and others v. Greece, 10 July 1998 (Appl. no. 26695/95), para. 40 . 
going beyond mere voting rights or majority rule. This also connects to the elaboration of civil society's role.

The case-law touching on aspects of civil society and civic space is quite elaborate and has spawned in the past few years. ${ }^{23}$ The Court has held that civil society performs two important functions in a democratic society: that of watchdog and that of provider of information to the general public. This identification of these critical and connected functions of civil society were first developed in the Court's jurisprudence in the 1980s in cases related to freedom of the press and have been confirmed many times since. ${ }^{24}$ In these cases, the Court virtually always emphasizes the "essential role of the press in a democratic society" in receiving and imparting information and performing a watchdog role. ${ }^{25}$ In 2004, in Vides Aizsardzïbas Klubs $v$. Latvia, the Court for the first time extended this recognition of a watchdog function beyond the media to a civil society organisation by referring to its essential function in a democracy. In that case, it concerned an environmental organisation which had criticised local authorities. The Court specified that in order to fulfil its role of watchdog well, an association should be enabled to inform the general public of facts that may interest it, to assess these facts and in doing so to contribute to the transparency of the work of public authorities. ${ }^{26}$

Whereas Vides Aizsardzibas Klubs concerned the freedom of expression element of Article 10 ECHR, in later cases the Court also recognised the social watchdog role of civil society when it comes to access to information over which the state has an informational monopoly. In that context it is relevant to assess whether an organisation has been involved in legitimate information gathering on an issue of public importance and whether its intention was to share such information with the public in order to contribute to public debate. ${ }^{27}$ And indeed, whenever such issues relate to information of

23 For a good recent overview, see e.g.: Selection of relevant case-law of the European Court of Human Rights made by Steering Committee for Human Rights (CDDH) (2018). A more in-depth analysis is provided by the Court itself in European Court of Human Rights (2016).

24 See e.g. ECtHR, Barthold v. Germany, 25 March 1985 (Appl.no. 8734/79), para. 58.

25 See e.g. ECtHR, Ukrainian Media Group v. Ukraine, 29 March 2005 (Appl. no. 72713/01) para. 38 .

26 ECtHR, Vides Aizsardzības Klubs v. Latvia, 27 May 2004 (Appl.no. 57829/00), para. 42.

27 See e.g., ECtHR (Grand Chamber), Magyar Helsinki Bizottság v. Hungary, 8 November 2016 (Appl.no. 18030/11), para. 132. 
public interest, actions by the state that interfere with this human right should be subjected to the most careful scrutiny. ${ }^{28}$ Put differently, when authorities thwart civil society in its role as watchdog or provider of information, this will be more difficult to justify under the ECHR. The same strict criteria as those pertaining to the freedom of the press when it informs the public of matters of general interest apply. ${ }^{29}$ This connects to several of the characteristics of civil society conducive to a democratic associational ecology, identified by Mark Warren ${ }^{30}$, namely an orientation to scrutinising the power of the state in order to promote public goods.

Thus, depending on the very role civil society plays in a particular situation, the protection of its rights may be higher. The Court also makes another differentiation, related to the content of civil society activism. In principle, organisations or individuals should have the freedom to advocate all types of changes, even those involving changes in a national constitution or institutions. An organisation cannot be refused formal registration, for example, merely because the state assesses its goals or activities will be political. As long as the organisation or the individuals behind it use legal and democratic means and as long as the proposed changes themselves are compatible with democracy. In a case about the refusal to register a Bulgarian organisation that wanted to re-establish the monarchy, the Court held: "the mere fact that an organisation demands such changes cannot automatically justify interferences with its members' freedoms of association and assembly." 31 The judgment has become relevant in many others contexts, as a number of states are seeking to especially limit activities of civil society organisations they dub as "political" to separate them from organisations that focus on the provision of services -a division that is mostly artificial and can lead to a compartmentalising that weakens civil society (Unmüßig 2016, 13). By contrast, as recounted above in the previous section, the Court does allow states to act against civil society organisations that advocate violence or hatred. Article $17 \mathrm{ECHR}$, the prohibition of the abuse of rights, can be applied by the Court in such cases to either declare an application inadmissible or to hold that the freedom of expression or association were not violated. Even if exceptions to the freedom

28 See e.g., ECtHR, Társaság a Szabadságjogokért v. Hungary, 14 April 2009 (Appl. no. 37374/05), para. 36 .

29 Vides Aizsardzības Klubs, para. 40.

30 See section 2.

31 ECtHR, Zhechev v. Bulgaria, 21 June 2007 (Appl.no. 57045/00), paras. 47-48. 
of association should be interpreted very strictly, in order to prevent arbitrariness or abuse of power by the state, democratic societies should be allowed to defend themselves. This could even ultimately entail dissolving an organisation that was propagating replacing democracy by another form of government. ${ }^{32}$ That type of action should remain highly exceptional, however.

Such differentiations in content also relate to another dimension. The Court offers a wide protection as to the ways and means employed under the freedom of expression and assembly. Free expression in the Convention protects not only the content of ideas expressed but also the ways in which they are conveyed. ${ }^{33}$ The same goes for assemblies, all kinds of which are protected under the Convention, from formal to informal, from static sit-ins to marches, and from public to private ones. But like in the case of freedom of expression, there is an outer limit which is linked to the notion of civility in civil society. Article 11 ECHR protects the freedom of peaceful assembly. Thus, the intentions of those organising the demonstration should be peaceful in order to be protected under the ECHR (European Court of Human Rights $2013,6-8)$. However, the mere risk of violence is not a sufficient reason for authorities to prohibit or disband an assembly. Rather, there is a positive obligation to enable demonstrations and to protect them against violence by counter-demonstrations. The Court has held on several occasions that "if every probability of tension and heated exchange between opposing groups during a demonstration were to warrant its prohibition, society would be faced with being deprived of the opportunity of hearing differing views on any question which offends the sensitivity of the majority opinion." 34 Any requirements or modalities the state places on demonstrations should be in strict accordance with the second paragraph of Article 11 ECHR that requires, like Article 10, that any restriction on the right at stake should be provided by law, should serve a legitimate aim and should be necessary in a democratic society. In early 2017, for example, the Court ruled that the Russian authorities had repeatedly undermined a series of local protests against corruption and, ironically, the repression of civil liberties. The authorities had done so by putting disproportionate and unjustified restrictions on the demonstrations, based on insufficiently

32 ECtHR, (admissibility decision), Kalifatstaat v. Germany, 11 December 2006 (Appl. no. $13828 / 04)$.

33 See e.g., ECtHR, Thoma v. Luxembourg, 29 March 2001 (Appl. no. 38432/97), para. 45.

34 Alekseyev v. Russia, para. 77. 
precise legal powers and the lack of legal remedies for the victims. Vague references by the authorities to possible acts of terrorism of extremism were not deemed a sufficient justification. ${ }^{35}$ The Court held back from concluding that there were structural attacks on civic space in Russia, however.

In the case-law dealt with here, the collective and individual dimensions of civic space are sometimes connected, for example in the principles relating to freedom of expression for individual journalists and for media organisations. The same goes for the freedom of assembly when individual protesters complain about being arrested of being prevented to organise demonstrations: these represent instances where individuals complain about participation in what for the most part are collective actions. However, there are also applications brought before the Court where the perspective is necessarily individual because of the right at stake. This concerns for example the killing or torture of human rights activists or their detention. ${ }^{36}$ Such individual experiences may have negative ramifications for civil society as a whole and thus for the enjoyment of human rights by others.

To point to these wider pernicious effects, the Court has developed its doctrine of "chilling effect". This doctrine entails that when assessing a particular expression, a balancing exercise by national courts or other authorities should not only include the effects on (particular) others of that expression, but also the "more general interest in promoting the free circulation of information and ideas [...] and the possible 'chilling' effect on others." 37 Although developed in the context of Article 10, it has also been applied in conjunction with Article 11 in cases were the Court held that disproportionate or unusually severe sanctions, such as long periods of detention, on protesters "must have had a chilling effect on the applicant and other persons taking part in protest actions." 38

The assessment that state action may have a wider chilling effect may be relevant for the Court in holding that the ECHR has been violated. But this is not the same concluding that a state is structurally diminishing rather than enabling civic space in a structural way. No

35 ECtHR, Lashmankin and Others v. Russia, 7 February 2017 (Appl. Nos 57818/09 and others).

36 Relating respectively to Articles 2 (right to life), 3 (prohibition of torture and inhuman and degrading treatment or punishment) and 5 (right to liberty) ECHR.

37 ECtHR, Steel and Morris v. the United Kingdom, 15 February 2005 (Appl. No. 68416/01), para. 95.

38 ECtHR, Taranenko v. Russia, 15 May 2014 (Appl.no 19554/05), para. 95. 
doctrine of a "chilling intent" has yet been explicitly developed by the Court, which would more justifiably enable it to require the state to make systemic changes rather than only providing individual relief.

A long dormant but in the last decade re-awakened tool within the Convention could serve that purpose of identifying a chilling intent: Article 18 ECHR. It provides that the "restrictions permitted under this Convention to the said rights and freedoms shall not be applied for any purpose other than those for which they have been prescribed." It entails, to phrase it differently, that state authorities had other, ulterior and political motives to restrict someone's rights, than they officially proclaimed. Finding a violation of this provision thus boils down to concluding that a state has acted in bad faith (Tan 2018, 127). The threshold for this is very high as a result, and it was only in 2017 that the Grand Chamber of the Court set out very specifically that the mere existence of other purposes than the officially proclaimed ones is not sufficient to find a violation of Article 18. The ulterior purpose should either have been the only underlying reason of the state's action or, if several purposes were pursued at the same time, the ulterior purpose should have been the predominant one. ${ }^{39}$

There is no space here to elaborate fully on all relevant aspects of this much-critiqued judgment and the Court's case-law on the matter ${ }^{40}$, but three aspects should be noted. Firstly, it will always be difficult to prove ulterior motives and thus context is important. The 2018 judgment in the case of Aliyev v. Azerbaijan is a landmark judgment on the civic space issue and illustrates this well. The case concerned a well-known human rights activist —including working as a lawyer representing applicants before the European Court of Human Rights itself - who had been arrested and whose house had been searched. In coming to the conclusion that Article 18 had been violated the Court took into account both the formal context of "increasingly harsh and restrictive legislation", the discourse of public officials stigmatising and delegitimising civil society organisations and their leaders as "traitors" and the wider practical space for civic action. As the Court phrased it: "In this connection, the applicant's situation cannot be viewed in isolation. Several notable human-rights activists who have cooperated with international organisations for the protection of human rights, including, most notably, the Council of

39 ECtHR (Grand Chamber), Merabishvili v. Georgia, 28 November 2017 (Appl. no. $72508 / 13)$, paras. 287-317.

40 For an extensive overview of Article 18 case-law, see: European Court of Human Rights (2018) 
Europe, have been similarly arrested and charged with serious criminal offences entailing heavy prison sentences. These facts support the applicant's and the third parties' argument that the measures taken against him were part of a larger campaign to 'crack down on humanrights defenders in Azerbaijan'"41.

A second element of note relates to the ensuing remedies once the Court finds a violation of Article 18. Under Article 46 ECHR, states are bound to abide by the final judgments of the Court, and this article has in some cases been used by the Court to indicate how specifically a state should remedy a problematic situation. This is especially the case when issues are structural and supersede the individual case. In Aliyev, the Court indeed did so and noted that the various judgments on similar issues it had delivered on the situation in Azerbaijan could not be considered to reflect isolated incidents. Rather they formed "a troubling pattern of arbitrary arrest and detention of government critics, civil society activists and human-rights defenders through retaliatory prosecutions and misuse of criminal law in defiance of the rule of law." As a result, the required remedial action by the state should entail general measures focused "as a matter of priority, on the protection of critics of the government, civil society activists and human-rights defenders against arbitrary arrest and detention. The measures to be taken must ensure the eradication of retaliatory prosecutions and misuse of criminal law against this group of individuals and the non-repetition of similar practices in the future". 42

Thirdly, most of the handful of Article 18 cases put an emphasis on the individual rather than the collective dimension of the civic space issue. After all, they are often submitted by individual human rights defenders who have been imprisoned or whose privacy has been interfered with by the state. Yet, the very application of that Convention provision enables the Court to look at the wider civil society context. The extent to which this is possible partly depends on third party interventions by civil society itself. Thus, as this section has shown, the case-law of the European Court has extensively developed protection for civil society and civic space and at the same time this

41 ECtHR, Aliyev v. Azerbaijan, 20 September 2018 (Appl. nos. 68762/14 and 71200/14), paras. 207-215. Importantly, it should be noted here that a substantial amount of this contextual information was brought before the Court by third party interventions of both civil society organisations and the Council of Europe's Commissioner for Human Rights.

42 Ibidem, paras. 223 and 226 respectively. 
development was brought about by the activities of civil society in its various formal and informal roles in the Convention system.

\section{Conclusion}

Civil society is a catch-all term and that makes it notoriously difficult to analyse. To a certain extent, the notion of civic space is too: once one adopts that frame, many human rights issues will seem to fall under this concept. As if, as soon as one wields a hammer, everything starts to look like a nail. Nevertheless, this article has argued that there is an important differentiation to be made within civil society, in terms of potential contributions to democracy and human rights. Civil society activists and organisations need civic space in order to perform their roles as watchdogs of those in power in the state and the market, as conveyors of information to the public, as advocates for public goods, and contributors to debates of general interest. But other parts of civil society could equally work against democracy, by using violent or nondemocratic means and by being conduits of power rather than spheres of free discourse among people. One should thus be weary of easy and automatic qualifications of civil society as being automatically beneficial to human rights and democracy.

The effectuation of the roles and work of civil society actors identified in social sciences literature depends on the safeguarding of their human rights. And at the same time, in an almost 'Siamese twin' type relationship, several parts of civil society can promote rights and give input to formal human rights institutions. This article has focused on the most prominent of such institutions, the European Court of Human Rights. It has argued that the ECHR system offers multiple ways in for civil society and also directly benefits from it. And simultaneously, it has shown how ECHR rights such as the freedoms of expression, assembly and association have been developed in the Court's case-law. In that jurisprudence lines can be traced which to an important extent reflect factors that contribute to a healthy democratic associational ecology. Obviously, the Court is not a panacea to all problems, not in the least because cases take years to be decided. But it does provide important normative and practical answers to the civic space issues of Europe today.

The current attacks on civic space, in their many manifestations, entail that the mutually beneficial relationship between the ECHR system and civil society actors can also be severely weakened. Ultimately, less space for civil society could mean that cases in which 
European adjudication is helpful would not even reach Strasbourg and that in other cases the information flows towards the Court as well as the implementation of its judgments are hampered. Civil society, after all, plays a role in all these dimensions of the Court's work. This means that intense Strasbourg scrutiny and an eye for the structural patterns in attacks on civic space are crucial, not just for the protection of civil society but also for the well-functioning of the European human rights machinery.

This brings us back to the current attacks on civic space and to Oyub Titiev, the human rights activist in Chechnya. In June 2019, he was released on parole after the decision of a local court. While this may be hailed as an individual success of the constant pressure put on the authorities by domestic and international human rights networks to free Titiev, the systemic issue has been far from solved. Titiev declared indeed that he would continue his human rights work but no longer in Chechnya and that he was afraid to ask any colleague to be active on human rights within that region because of the risks. So the Chechnyan leader Kadyrov may have gotten his way after all. It certainly points to the mixed bag of success and failure in attempt to effectively counter attacks on civic space. As the European Parliament has noted for example, the EU has been relatively successful in getting human rights defenders out of immediate danger, but it has proven much more difficult to address the deeper structural problems faced by civil society (Youngs and Echagüe 2017,6). As this article has tried to show, the European Convention on Human Rights and its Court, with its close and mutually beneficial relationship with civil society and its elaborate and refined normative framework developed in its case-law, may be part of the essential tools to do so.

\section{References}

Anheier, Helmut K. 2004. Civil society. Measurement, evaluation, policy, London: Earthscan.

Bürli, Nicole. 2017. Third-party interventions before the European Court of Human Rights, Cambridge: Intersentia.

Buyse, Antoine. 2014. "Contested contours: the limits of freedom of expression from an abuse of rights perspective: Articles 10 and 17 ECHR", in Shaping rights in the ECHR. The role of the European Court of Human Rights in determining the scope of human rights, edited by E. Brems and J. Gerards, 183-208, Cambridge: Cambridge University Press.

Buyse, Antoine. 2018. "Squeezing civic space: restrictions on civil society organizations and the linkages with human rights", The 
International Journal of Human Rights, 22 (8): 966-988, DOI: 10.1080/13642987.2018.1492916.

Carothers, Thomas, and Brechenmacher, Saskia. 2014. Closing space: Democracy and Human Rights support under fire, Washington DC: Carnegie Endowment for International Peace, Accessed June 19, 2019. www.carnegieendowment.org/files/closing_space.pdf

Centre for Civil Society. 2006. Report on activities July 2005-August 2006, London: The London School of Economics and Political Science, Accessed June 19, 2019. http://eprints.Ise.ac.uk/29398/1/CCSReport05_06.pdf

Cichowski, Rachel. 2010. Civil society and the European Court of Human Rights, APSA Annual Meeting Paper. Accessed June 19, 2019. https://ssrn. com/abstract $=1643604$

CIVICUS. 2018. People power under attack. A global analysis of threats to fundamental freedoms Accessed June 9, 2019. https://www.civicus.org/ documents/PeoplePowerUnderAttack.Report.27November.pdf

Coelho, Letícia. 2017. "Infographics: Civic space explained", Sur International Journal on Human Rights, 14 (26): 193-197.

Cooper, R. 2018. What is civil society? How is the term used and what is seen to be its role and value (internationally) in 2018? K4D Helpdesk Report, Brighton, UK: Institute of Development Studies. Accessed June 19, 2019. https://opendocs.ids.ac.uk/opendocs/bitstream/ handle/123456789/14242/488_What_is_Civil_Society.pdf?sequence=1\&is Allowed=y

Chambers, S., and Kopstein, J. 2001. "Bad civil society", Political Theory, 29: 837-865.

Edwards, Michael. 2011. "Introduction: Civil society and the geometry of human relations" in The Handbook of Civil Society, edited by Michael Edwards, 3-14 Oxford: OUP.

Edwards, Michael. 2014. Civil Society, $3^{\text {rd }}$ edition, Cambridge: Polity Press.

European Court of Human Rights. 2013. Article 11: The conduct of public assemblies in the Court's case-law. Accessed June 19, 2019. https://www. echr.coe.int/Documents/Public_assemblies_ENG.pdf

European Court of Human Rights. 2016. Rapport de recherché. Les organisations non gouvernementales dans la jurisprudence de la Cour européenne des droits de l'homme. Accessed June 19, 2019. https://www. echr.coe.int/Documents/Research_report_NGOs_FRA.PDF

European Court of Human Rights. 2018. Guide on Article 18 of the European Convention on Human Rights - Limitation on use of restrictions on rights. Accessed June 19, 2019. www.echr.coe.int/Documents/Guide_Art_18_ ENG.pdf

Glasius, Marlie. 2016. "Civil and uncivil society", The Blackwell Encyclopedia of Sociology online, Accessed June 19, 2019. https://doi.org/10.1002/9781405165518.wbeos0714

Human Rights Watch. 2016. World Report 2016: How the Politics of Fear and the Crushing of Civil Society Imperil Global Rights. Accessed June 19, 2019. www.hrw.org. 
Human Rights Watch. 2018. "Russia: Chechen leader threatens human rights defenders", The Guardian, 28 August. Accessed June 19, 2019. http:// www.theguardian.com

Lettinga, Doutje \& Kaulingfreks, Femke. 2015. "Clashing activisms: International human rights organizations and unruly politics", Journal of Human Rights Practice, 7 (3): 343-365, Accessed June 19, 2019. https:// doi.org/10.1093/jhuman/huv015

McIntosh Sundstrom, Lisa. 2014. "Russian NGOs and the European Court of Human Rights: A spectrum of approaches to litigation", Human Rights Quarterly, 36: 844-868.

Steering Committee for Human Rights (CDDH). 2018. Drafting group on civil society and national human rights institutions, 8 February, CDDHINST(2018)02, Accessed June 19, 2019. https://rm.coe.int/steeringcommittee-for-human-rights-cddh-drafting-group-on-civil-socie/1680787474

Tan, Floris. 2018. "The dawn of Article 18 ECHR: A safeguard against European rule of law backsliding?", Goettingen Journal of International Law, 9 (1): 109-141.

The Guardian. 2019. "Court in Chechnya banishes human rights activist to penal colony", The Guardian 19 March. Accessed June 19, 2019. www. theguardian.com

The Moscow Times. 2016. "Rights group memorial declared «foreign agent»" (for criticizing law about «foreign agents»)', 4 October. Accessed June 19, 2019. www.themoscowtimes.com.

Unmüßig, Barbara. 2016. Civil society under pressure - shrinking - closing no space Berlin: Heinrich Böll Foundation. Accessed June 19, 2019. www. boell.de

Van der Borgh, Chris, and Carolijn Terwindt. 2014. NGOs under pressure in partial democracies, Basingstoke: Palgrave Macmillan.

Warren, Mark E. 2011. "Civil society and democracy", in The Handbook of Civil Society, edited by Michael Edwards, 377-390, Oxford: OUP.

Wischermann, Jörg, Bettina Bunk, Patrick Köllner and Jasmin Lorch. 2018. "Do associations support authoritarian rule? Evidence from Algeria, Mozambique, and Vietnam", Journal of Civil Society, 14 (2): 95-115.

World Economic Forum (WEF). 2013. The future role of civil society. Accessed June 19, 2019. www3.weforum.org/docs/WEF_FutureRoleCivilSociety Report_2013.pdf

Youngs, Richard and Ana Echagüe. 2017. Shrinking space for civil society: EU Response, Brussels: European Parliament. Accessed June 19, 2019. http:// www.europarl.europa.eu/RegData/etudes/STUD/2017/578039/EXPO_ STU(2017)578039_EN.pdf 


\section{Copyright}

Deusto Journal of Human Rights / Revista Deusto de Derechos Humanos is an Open Access journal; which means that it is free for full and immediate access, reading, search, download, distribution, and reuse in any medium only for non-commercial purposes and in accordance with any applicable copyright legislation, without prior permission from the copyright holder (University of Deusto) or the author; provided the original work and publication source are properly cited (Issue number, year, pages and DOI if applicable) and any changes to the original are clearly indicated. Any other use of its content in any medium or format, now known or developed in the future, requires prior written permission of the copyright holder.

\section{Derechos de autoría}

Deusto Journal of Human Rights / Revista Deusto de Derechos Humanos es una revista de Acceso Abierto; lo que significa que es de libre acceso en su integridad inmediatamente después de la publicación de cada número. Se permite su lectura, la búsqueda, descarga, distribución y reutilización en cualquier tipo de soporte sólo para fines no comerciales y según lo previsto por la ley; sin la previa autorización de la Editorial (Universidad de Deusto) o la persona autora, siempre que la obra original sea debidamente citada (número, año, páginas y DOI si procede) y cualquier cambio en el original esté claramente indicado. Cualquier otro uso de su contenido en cualquier medio o formato, ahora conocido o desarrollado en el futuro, requiere el permiso previo por escrito de la persona titular de los derechos de autoría. 